\title{
H. Larkins
}

\section{Die voorsetselwerkwoord in die werkwoordstelsel van Afrikaans}

\begin{abstract}
There is much confusion concerning the prepositional verb as a separate category main verb in Afrikaans. Some linguists are of the opinion that the prepositional verb is not a separate category main verb, but rather $a$ subcategory transitive or intransitive verb. There is a definite need for parameters within which the prepositional verb should feature. The unique characteristics of the prepositional verb necessitate the need for it to be classified as a separate category, and the need that the relation between the prepositional verb and the particle be highlighted.
\end{abstract}

\section{Inleidend}

Met die verskyning van F.A. Ponelis se Grondtrekke van die Afrikaanse sintaksis in 1968, het die benaming voorsetselwerkwoord in die kollig beland. In sy Afrikaanse sintaksis wat in 1979 verskyn het, word daar baie meer gesê oor dié tipe werkwoord (vergelyk Ponelis, 1979:216, 457, 824). Sedertdien is daar baie gegis oor die bestaan van so 'n tipe werkwoord en hoe dit geklassifiseer behoort te word.

Die taaloefeninge in voorgeskrewe handboeke wat deur leerlinge in primêre en sekondêre skole gebruik word, ignoreer werkwoorde soos beskik, hou, hunker of toelê en fokus eerder op voor die hand liggende gevalle as op die problematiese.

Bronne wat deur tersiêre inrigtings gebruik word, verwys sydelings na voorsetselwerkwoorde as 'n subklas van die kategorieë oorganklike en onoorganklike werkwoorde of as werkwoorde wat soms deur 'n vaste voorsetsel gevolg word, maar dikwels daarsonder kan optree. Ewe dikwels is die voorbeelde van 'voorsetselwerkwoorde' eintlik onoorganklike werkwoorde wat toevallig deur 'n voorsetselgroep gevolg kan word. 
Sekondêre leerplanne van die onderskeie onderwysdepartemente maak nie voorsiening vir die bestudering van ' $n$ werkwoordstelsel in Afrikaans waarbinne voorsetselwerkwoorde figureer nie. Ook op tersiêre vlak gee leerplanne weens die leemte in handboeke nie aandag aan die verskynsel nie. In verskillende handboeke word verskillende menings gehuldig in verband met voorsetselwerkwoorde. So byvoorbeeld word deur De Beer en Van Staden (1968:131) 'n benadering gevolg waar die volgende voorbeelde as voorsetselwerkwoorde beskou word:

Die man staan op die tafel.

Die man staan langs die tafel.

Om te bepaal wat taalkundiges se siening van die voorsetselwerkwoord is, is ' $n$ studievraelys aan al die universiteite en kolleges gestuur. Die inligting wat uit hierdie vraclyste verkry is, is verwerk ten einde relevante afleidings te kon maak.

Met die toestemming van die respondente is interessante menings ten opsigte van die voorsetselwerkwoord in die artikel vervat. Vrae soos die volgende is deur die respondente beantwoord:

- Word sintaksis as 'n aparte dissipline aan $u$ inrigting aangebied?

- Watter bronne word as uitgangspunt vir $\mathrm{u}$ aanbieding van sintaksis gebruik?

- Hoeveel klasse hoofwerkwoorde word in u aanbieding onderskei?

- Word die voorsetselwerkwoord as 'n aparte kategorie hoofwerkwoord in u aanbieding geklassifiseer?

- Stem u met die volgende stellings saam?

- Die voorsetselwerkwoord bestaan nie as 'n kategorie hoofwerkwoord in Afrikaans nie.

- Die voorsetselwerkwoord is slegs ' $n$ bepaalde tipe oorganklike of onoorganklike werkwoord.

\subsection{Die steekproefgrootte}

39 vraelyste is aan tersiêre instansies gestuur: 19 aan universiteite, 16 aan onderwyskolleges en 4 aan tegniese kolleges. Na onbevredigende respons is 'n opvolgvraelys gestuur aan die inrigtings wat nie op die eerste vraelys gereageer het nie. 'n Respons van $58,97 \%$ is toe verkry en die steekproef kon as genoegsaam beskou word om bruikbare ontledings uit te voer 
Op sekondêre vlak is geen vraelys uitgestuur nie, omdat sekondêre instansies aan 'n voorgeskrewe kemleerplan gebonde is. Die sillabusse van al vier die provinsies is vooraf geraadpleeg en dit het aan die lig gekom dat al die provinsies se onderwysdepartemente 'n weergawe van die werkwoordstelsel gegee het wat byna woordeliks met mekaar ooreenstem en waarbinne die voorsetselwerkwoord geen plek beklee het nie.

\begin{tabular}{|l|c|c|c|}
\hline Tersiêre instansies & Reaksie & Geen Reaksie & Totaal \\
\hline Universiteite & 12 & 7 & 19 \\
\hline Kolleges & 8 & 8 & 16 \\
\hline Tegniese kolleges & 3 & 1 & 4 \\
\hline Totaal & $\mathbf{2 3}$ & $\mathbf{1 6}$ & $\mathbf{3 9}$ \\
\hline
\end{tabular}

\subsection{Die ontvangs en kontrole van die vraelyste}

Die voltooide vraelyste is met ontvangs gekontroleer. Veranderlikes soos dissiplines, vlakke, bronne en kwalifikasies is ten opsigte van volledigheid nagegaan. Die data is verwerk ten einde relevante afleidings te kon maak.

Die leemtes en beperkings ten opsigte van die navorsing moet gesien word teen die agtergrond van die volgende faktore:

- die relatıet klein steekproef;

- respondente se ongemotiveerdheid om op die vraelys te reageer en terugvoering te gee, en

- die bepalende invloed wat van die onderwyssillabusse uitgegaan het.

Du Plessis (1982:79) beskou voorsetselwerkwoorde as 'n subklas van oorganklike en onoorganklike werkwoorde, terwyl Prins van die Universiteit van Fort Hare (studievraclys) die volgende mening huldig:

Die feit dat bepaalde werkwoorde deur voorsetsels gevolg word, is ' $n$ toevalligheid. In die oorgrote meerderheid gevalle is die keuse van die voorsetsel bowendien relatief vry. Die gevalle waar die voorsetsel 'voorgeskryf' is omdat dit saam met die werkwoord ' $n$ vaste verbinding vorm, is eweneens 'n toevalligheid.

Bogenoemde dui daarop dat daar ' $n$ Babelse verwarring bestaan of die 'sogenaamde' voorsetselwerkwoorde kan aanspraak maak op die status van 'n aparte kategorie hoofwerkwoord binne die werkwoordstelsel van Afrikaans, en of 
dit slegs 'n subkategorie van die oorganklike of onoorganklike werkwoorde is wat toevallig soms ' $\mathrm{n}$ vaste voorsetsel determineer.

Ponelis (1979:216-217) verduidelik voorsetselwerkwoorde soos volg:

Die voorsetselwerkwoorde verbind heg met voorsetselgroepe. By heelparty werkwoorde is die verbinding so heg dat die voorsetselgroep nie weggelaat kan word nie:

\section{Hulle teer op die staat. \\ * Hulle teer.}

By ander voorsetselwerkwoorde kan die voorsetselgroep egter wel ontbreek:

Hy stry heeldag met my.

Hy stry heeldag.

Hier impliseer Ponelis dus dat hoewel die voorsetselgroep weglaatbaar is, die werkwoord steeds ' $n$ voorsetselwerkwoord is. Botha en Van Aardt (1987:70) sluit hierin by Ponelis aan:

Soms is die verbinding tussen voorsetselwerkwoord en voorsetsel(groep) so heg dat die voorsetselgroep geheel en al onweglaatbaar is, byvoorbeeld:

Sy dapperheid grens aan domastrantheid.

* Sy dapperheid grens.

Soms is die band nie so heg nie, byvoorbeeld:

Die gemeente bid om reën.

Die gemeente bid.

Botha en Van Aardt (1987) versuim egter om dit duidelik te stel of die werkwoord steeds 'n voorsetselwerkwoord is indien die voorsetselgroep ontbreek en of hulle dit as ' $n$ ander tipe hoofwerkwoord (byvoorbeeld ' $n$ onoorganklike werkwoord) beskou indien die voorsetselgroep weggelaat kan word

De Villiers (1983:104) stel dit dat daar werkwoorde met ' $n$ vaste voorsetsel bestaan waarvoor daar nie ' $n$ algemeen aanvaarde naam is nie en wat ons maar voorsetselwerkwoorde kan noem. Hy meld dat die tipe werkwoord met sy voorsetsel 'n semantiese eenheid, net soos die partikelwerkwoord (deeltjiewerkwoord), vorm en daarom ' $n$ tipe verbinding is wat aan die partikelwerkwoord verwant is. Dit is dus ' $n$ verbinding van ' $n$ werkwoord en ' $n$ komplement wat semanties as ' $\mathrm{n}$ eenheid beskou moet word, byvoorbeeld hou van; aard na; behoort aan; reken op; reken af met: gaan in op. Anders as die partikelwerkwoord waar die komplement ' $n$ adjunk is, is die komplement by 'n 
voorsetselwerkwoord 'n voorsetsel. De Villiers (1983: 139) verwoord sy siening rondom die problematiek van die voorsetselwerkwoord soos volg:

Dis dikwels moeilik om uit te maak of daar in 'n bepaalde konstruksie ' $n$ voorsetselwerkwoord is met ' $n$ vaste voorsetsel en of die eenheid beperk is tot werkwoorde en naamwoorde, terwyl die voorsetsel daarbuite val.

Dit alles laat die vraag ontstaan of daar inderdaad so iets soos 'n voorsetselwerkwoord is, en indien wél, hoe dié tipe werkwoord dan optree.

Uit die studievraelyste wat aan respondente aan universiteite en onderwyskolleges gestuur is, blyk dit duidelik dat die voorsetselwerkwoord die meeste probleme van al die hoofwerkwoorde oplewer. Groot verwarring heers veral ten opsigte van oorganklikheid by die voorsetselwerkwoord. Die vraag of die voorsetselwerkwoord dan inderdaad as ' $n$ aparte kategorie hoofwerkwoord beskou kan/behoort te word, het uiteenlopende opinies van die respondente ontlok. Die volgende menings is onder andere uit die navorsingsvraelyste geneem:

Mev. Kirchner van die Windhoekse Onderwyskollege spreek haar soos volg oor die problematiek uit:

Alhoewel ek al dikwels getwyfel het of die voorsetselwerkwoord wel apart onderskei behoort te word, lyk hierdie onderskeiding tog nuttig. Dit is egter duidelik dat dit nie ' $n$ werkwoord apart van ander klasse kan wees nie.

De Vos van die Durbanse Onderwyskollege (studievraelys) sal 'n saak wil uitmaak dat die voorsetselwerkwoord en die wederkerende werkwoord onnodig is en as subklasse van die oorganklike en onoorganklike werkwoord ondervang kan word. Hierdie beskouing van De Vos sluit by Du Plessis (PU vir CHO) aan wat hom soos volg uitspreek: "Die voorsetselwerkwoord is 'n besondere soort oorganklike of onoorganklike werkwoord" (studievraelys).

Ponelis (1979:216) bespreek die voorsetselwerkwoord breedvoerig, maar in die vraelys beweer hy dat die voorsetselwerkwoord nie as 'n aparte kategorie werkwoord in Afrikaans bestaan nie. Daar word aanvaar dat hierdie uitspraak 'n blote vergissing is, omdat sy kategorisering van die daaropvolgende hoofwerkwoorde wel deeglik die teendeel uitstippel.

Uit die voorafgaande aanhalings en verwysings uit die navorsingsvraelyste blyk dit duidelik dat die verwarring rondom die voorsetselwerkwoord selfs groter is as wat aanvanklik vermoed is. Dat daar dan inderdaad ' $n$ behoefte aan maatstawwe en norme is waarvolgens ' $n$ werkwoord soos bekroon in Die Akademie bekroon hom met die Hertzogprys geklassifiseer kan word, blyk duidelik uit die figuur. 


\section{Figuur 1}

Die Akademie bekroon hom met die Hertzogprys

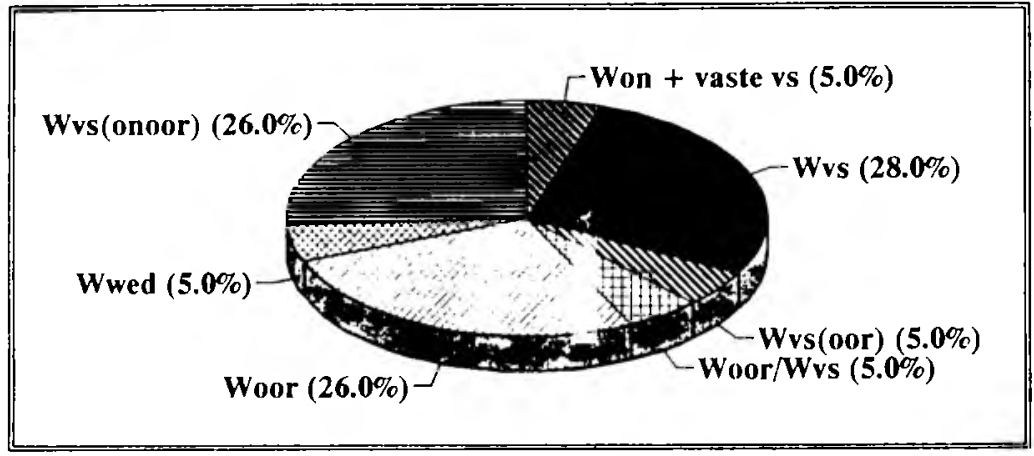

In hierdie $\sin$ is die hoofwerkwoord soos volg gekategoriseer: $28 \%$ sien dit as ' $n$ voorsetselwerkwoord, sonder 'n verdere spesifisering of dit 'n voorsetselwerkwoord is wat oorganklik gebruik is of ' $n$ voorsetselwerkwoord wat onoorganklik gebruik is; $26 \%$ meld spesifiek dat die voorsetselwerkwoord hier onoorganklik gebruik is, terwyl 'n verdere $26 \%$ dit weer as 'n oorganklike werkwoord beskou; $5 \%$ is van mening dat dit ' $n$ onoorganklike werkwoord is wat met 'n vaste voorsetsel verbind; ' $n$ verdere $5 \%$ beskou dit as 'n wederkerende werkwoord; $5 \%$ is van mening dat dit 'n oorganklike werkwoord of ' $n$ voorsetselwerkwoord kan wees, terwyl $5 \%$ spesifiek meld dat die werkwoord 'n oorganklike voorsetselwerkwoord is.

Hoe funksioneer 'n (sogenaamde) voorsetselwerkwoord dan eintlik? Watter rol speel die voorsetsel in die klassifisering? Kan 'n voorsetselwerkwoord soms sonder die voorsetselgroep optree (Ponelis, 1979:217)? Is die voorsetselwerkwoord slegs 'n besondere soort oorganklike of onoorganklike werkwoord? Hierdie vrae word in dié artikel onder die loep geneem.

\section{Die wesenskenmerke van die voorsetselwerkwoord}

Uit die data wat uit die studievraelyste en taalkundebronne bestudeer is, het dit duidelik geword dat die voorsetselwerkwoord 'n gekompliseerde tipe hoofwerkwoord is wat in subkategorieë of 'tipes' verdeel kan word. By sommige voorsetselwerkwoorde was die verbintenis met die voorsetsel so heg dat die weglating van die voorsetsel 'n totaal ongrammatiese sin tot gevolg sou hê. Die sprekendste 
voorbeelde hiervan is respektiewelik deur Ponelis (1979:217), asook deur Botha en Van Aardt (1987:69) aangeteken:
* Hulle teer.
Hulle teer op die staat.
Hans hou van koedoebiltong.
* Hans hou.

Wanneer daar getoets word of 'n bepaalde hoofwerkwoord 'n voorsetselwerkwoord is, moet die sin met die gewaande voorsetselwerkwoord basies dieselfde semantiese waarde hê as die gewysigde konstruksie(s) van dieselfde sin, byvoorbeeld:
(a) Tom bou nog aan die huis.
(b) Tom bou nog die huis.
(c) Tom bou nog.
(d) Tom bou nog in die huis.

Die semantiese waarde van sin (a) verskil geheel en al van dié van elke ander sin, naamlik (b), (c) en (d). Hierdie drie voorbeelde kan dus nie gekategoriseer word as 'n ander vorm', of ' $n$ afskaling', of 'eweknie' van 'n voorsetselwerkwoord nie!

Soms is die verbintenis tussen die voorsetselwerkwoord en die voorsetselgroep nie so heg nie en kan die voorsetselgroep weggelaat word, sodat die voorsetselwerkwoord as 'n oorganklike of onoorganklike werkwoord optree, byvoorbeeld:

Die gemeente bid om reën (voorsetselwerkwoord).

Die gemeente bid (onoorganklike werkwoord) (Botha \& Van Aardt, 1987:70).

Ek sal jou beskerm teen gevare (voorsetselwerkwoord).

Ek sal jou beskerm (oorganklike werkwoord).

Dit het verder ook duidelik geword dat Ponelis (1979:276) se voorsetseladjektiewe in dié opsig probleme oplewer, naamlik dat dit telkens met 'n koppelwerkwoord moet verbind, ten einde die ooreenkoms met 'n sekere voorsetselwerkwoord moontlik te maak. Die voorsetseladjektief + koppelwerkwoord wat soos 'n voorsetselwerkwoord optree, is dus duidelik nie op dieselfde vlak as die voorsetselwerkwoord sélf nie. Dat die voorsetselwerkwoord inderdaad 'n besondere, maar eiesoortige kategorie hoofwerkwoord is, blyk uit die wesenskenmerke wat hierdie bepaalde tipe hoofwerkwoord onderlê. 


\subsection{Voorsetselwerkwoorde determineer 'n vaste voorsetsel}

Die belangrikste kenmerk van die voorsetselwerkwoord is dat dit 'n vaste voorsetsel determineer. Indien die werkwoord heg met ' $n$ verpligte onderdeel van die sin verbind, geskied hierdie verbinding deur middel van 'n voorsetsel (Botha, 1985:69). In teenstelling met die siening van Prins van die Universiteit van Fort Hare (studievraelys) dat die keuse van die voorsetsel relatief vry is, blyk dit uit die ondersoeker se navorsing dat die voorsetsel betreklik vas is en in die oorgrote meerderheid gevalle nie deur ' $n$ ander voorsetsel vervang kan word sonder dat die betekenis van die sin gewysig word nie.

Voorbeelde van werkwoorde wat 'n vaste voorsetsel determineer, is swig (voor), reken (op), heul (met), aard (na), beskik (oor) behoort (aan), berus (op), akkordeer (met). Die gedeternineerde voorsetsel vorm saam met die daarmee gepaardgaande naamwoordstuk ' $n$ voorsetselgroep. Die naamwoordstuk wat in so ' $n$ voorsetselgroep optree, word reeds in Ponelis (1968:10) ' $n$ voorsetselvoorwerp genoem:

\begin{tabular}{|c|c|c|c|c|c|}
\hline & Wvs & 1 & vs & 1 & voorsetselvoorwerp \\
\hline Almal & smag & 1 & na & 1 & rus en vrede. \\
\hline e regering & beskik & I & oor & 1 & inligting. \\
\hline
\end{tabular}

Van Schoor (1983:192) verwys na die gedetermineerde voorsetsel as die voorsetselsupplement en na die voorsetselvoorwerp as die komplement.

- Die voorsetselwerkwoord + vaste voorsetsel + NS

Die voorsetselwerkwoord word saam met die vaste voorsetsel gegee:

Hulle teer op die staat (Ponelis, 1979:217).

Hy beskik oor inligting (Botha \& Van Aardt, 1987:37).

Almal smag na 'n ruskansie.

Hulle heul met die vyand.

Die seelug akkordeer met hom.

Sy aard na haar ma.

Dit berus op tradisie. 
Die bundel bestaan uit tien verhale.

Albei behoort aan die vereniging.

Almal hunker na rus en vrede.

Hy berus in die onvermydelike.

Ons reken $o p$ julle steun.

Sommige voorsetselwerkwoorde kan met meer as een (maar gewoonlik nie meer as twee of drie) voorsetsels gebruik word:

Ons glo in die Heilige Gees.

Ons glo aan 'n heilige, algemene kerk.

Die finale besluit berus by die hoof.

Die beslissing berus op deeglike ondersoek (Van Schoor, 1983:193).

\subsection{Voorsetselwerkwoorde vereis 'n voorsetselgroep}

Die verbinding tussen die voorsetselwerkwoord en die betrokke voorsetselgroep is so heg dat die voorsetselgroep nie weggelaat kan word nie (Botha, 1978:112). Ponelis (1979:216) stel dit dat die verbinding by heelparty werkwoorde so heg is dat die voorsetselgroep nie weggelaat kan word nie, maar (dat) by voorsetselwerkwoorde die voorsetselgroep egter wel kan ontbreek, soos in:

Hy stry heeldag met my.

Hy stry heeldag.

Die regering besin nog oor die stelsel.

Die regering besin nog.

Bogenoemde voorbeelde dien ter stawing van sy redenasie. Hierdie uitspraak van Ponelis is egter ' $n$ contradictio in terminis omdat dit ' $n$ wesenseienskap van die voorsetselwerkwoord is dat dit ' $n$ voorsetselgroep vereis waarmee dit heg verbind. Sodra die werkwoord sonder die noodsaaklike voorsetselgroep optree, kan dit nie meer die kenmerke van 'n voorsetselwerkwoord openbaar nie, maar tree dit as onoorganklike werkwoord op.

Van Schoor (1983:193) stel dit dat daar werkwoorde is wat in een betekenis 'n voorsetselwerkwoord is, maar in ' $n$ ander nie: 
Hy reken hoeveel dit hom sal kos.

Hy reken op ons hulp.

Hy stel dit ook duidelik dat werkwoorde soms met en soms sonder voorsetselsupplement gebruik word met behoud van die betekenis van die sin:

Hy vra hulp.

Hy vra om hulp (Van Schoor, 1983:78).

Botha (1985:70) sluit by Ponelis se uitspraak aan:

Soms is die verbinding tussen voorsetselwerkwoord en voorsetsel(groep) so heg dat die voorsetselgroep geheel en al onweglaatbaar is, byvoorbeeld:

Sy dapperheid grens aan domastrantheid

* Sy dapperheid grens.

Soms is die band nie so heg nie, byvoorbeeld:

Die gemeente bid om reen.

Die gemeente bid (Botha, 1985:70-78).

Uit die teks is dit egter moeilik om vas te stel of Botha suggereer dat die werkwoord wat soms sonder die noodsaaklike voorsetselgroep optree, steeds 'n voorsetselwerkwoord is, en of dit in hierdie geval dan 'n onoorganklike werkwoord is.

Dit het veral uit die literatuurstudie duidelik geword dat die voorsetselgroep wat met die voorsetselwerkwoord verbind, heel dikwels binne die konteks van 'n gespreksituasie weggelaat kan word, omdat die voorsetselgroep aan die gespreksgenote bekend is of afgelei kan word:

Die veroordeelde gaan glo appelleer (teen sy vonnis).

Ek sal jou beskerm (teen gevare).

Die skrywer is bekroon (met die Hertzogprys).

Ek wil ook bydra (tot die hulpfonds).

Moenie my beskuldig (van verraad) nie.

Wie van julle stel belang (in goedkoop vleis)?

Ek wil jou gelukwens (met jou verjaardag). 
In bogenoemde gevalle het die vraag ontstaan of die hoofwerkwoord, sonder die voorsetselgroep dan tot 'n oorganklike of onoorganklike werkwoord gewysig word. Hierdie problematiek word nie deur Ponelis (1979:216) of Botha (1985: 70 ) bevredigend belig nie, omdat Ponelis se uitspraak ' $n$ wesenskenmerk van die voorsetselwerkwoord aantas, naamlik dat dit 'n voorsetselgroep vereis. Botha en Van Aardt (1978:70) laat weer na om hulle duidelik uit te spreek of hulle die werkwoord, wat sonder sy voorsetselgroep as aanvulling optree, steeds as 'n voorsetselwerkwoord beskou.

Dit bly egter die taak van die taalkundige om die reëls wat die taal ten grondslag lê, bloot te lê en te beskrywe. Die reël in verband met die voorsetselwerkwoord is reeds toegelig, naamlik dat só 'n werkwoord 'n voorsetselgroep vereis wat heg met die voorsetsel daarvan verbind. Indien die betrokke voorsetselgroep ontbreek, soos die geval is by Ponelis (1979:217), kan ons dus nie sê dat die werkwoord 'n voorsetselwerkwoord is nie, omdat die hoofwerkwoord hier dan as 'n onoorganklike werkwoord optree.

\subsection{Die voorsetselgroep wat via die vaste voorsetsel met die voorsetsel- werkwoord verbind, is nie sonder meer vervangbaar deur een woord nie}

Daar is reeds op twee wesenseienskappe van die voorsetselwerkwoord gewys, naamlik dat 'n vaste voorsetsel determineer en dat dié voorsetselgroep gevolg word deur' $n$ voorsetselvoorwerp.

'n Derde kenmerkende eienskap waaraan die voorsetselwerkwoord voldoen, is dat die voorsetselgroep wat saam met die voorsetselwerkwoord optree, nie sonder meer deur een woord vervang kan word nie (Botha \& Van Aardt, 1987:112). Vergelyk sin (a) en (b):

(a) Die boeke lê op die tafel.

(b) Die polisie beskik oor inligting.

In $\sin (\mathrm{a})$ is dit moontlik om die voorsetselgroep weg te laat, sonder dat die wesenlike betekenis van die sin gewysig word: Die boeke lê (iewers). Dit is verder ook moontlik om die voorsetsel op met 'n verskeidenheid moontlikhede te vervang:

Die boeke lê /onder/ die tafel.

/langs/

/by/ 


\section{lagter/}

Die voorsetselgroep in sin (a) kan boonop sonder enige probleme deur een woord soos daar. iewers, êrens vervang word, sonder dat die basiese betekenis van die sin gewysig word, want die semantiese waarde van die sinne bly steeds:

Die boeke lê iewers.

Hierteenoor is $\sin (b)$ baie meer rigied, omdat die verskillende onderdele van die sin ter wille van die betekenis juis nie fakultatief is nie. 'n Mens merk byvoorbeeld dadelik op dat die voorsetsel nie sonder meer deur enige ander voorsetsel vervang kan word nie:

* Die polisie beskik /met/ inligting.

$$
\begin{aligned}
& \text { */van/ } \\
& \text { */deur/ } \\
& \text { */op/ }
\end{aligned}
$$

Die betrokke voorsetselgroep kan ook nie weggelaat word, sonder dat 'n semantiese 'leegheid' ontstaan nie:

* Die polisie beskik.

Eweneens leen die voorsetselgroep hom nie tot vervanging deur één woord nie:

* Die polisie beskik feite.

Pogings om in die volgende sinne die voorsetselgroepe deur een woord te vervang, is ewe futiel:

Die feesvieringe berus $o p$ tradisie.

* Die feesvieringe berus dit.

Sy aard baie beslis na haar ma.

* Sy aard baie beslis haar.

Die seelug akkordeer met hom.

* Die seelug akkordeer Piet.

Ons almal behoort aan die vereniging.

* Ons almal behoort leserskring

\section{Die optrede van die voorsetselwerkwoord}

In die vorige afdeling is die algemene wesenskenmerke van die voorsetselwerkwoord soos volg uitgelig: 
- Die voorsetselwerkwoord determineer ' $n$ vaste voorsetsel.

- Die voorsetselwerkwoord vereis 'n voorsetselgroep.

- Die voorsetselgroep wat saam met die voorsetselwerkwoord optree, kan nie sonder meer deur een woord vervang word nie (Botha, 1978:112).

In wese is die voorsetselwerkwoord dus ' $n$ besondere kategorie hoofwerkwoord wat veral in noue verbintenis optree met ' $n$ vaste voorsetsel wat ' $n$ voorsetselgroep. Die naamwoordstuk in só 'n voorsetselgroep word 'n voorsetselvoorwerp genoem (Ponelis, 1968:10). Afgesien van die voorsetselgroep kan sekere voorsetselwerkwoorde terselfdertyd met 'n tweede item verbind, naamlik 'n gewone naamwoordstuk wat as voorwerp funksioneer.

\subsection{Wvs + NS + vaste VG}

Voorsetselwerkwoorde determineer soms benewens die voorsetsel(groep) 'n naamwoordstuk wat as 'n voorwerp van die werkwoord optree. So 'n voorsetselwerkwoord het dus boonop oorganklike werkwoordkenmerke:

Sy herinner hom aan die vergadering (Botha \& Van Aardt, 1987:72).

Hy maak melding van die gebeure.

Ek doen ' $n$ beroep op jou goedhartigheid.

Onderling verskil hierdie sinne ook van mekaar en val in twee duidelike groepe uiteen. Let op die volgende sin:

Sy herinner hom aan die vergadering.

Hier is die verbinding tussen herinner en aan die vergadering byvoorbeeld baie hegter as die verbinding tussen herinner en hom. In die volgende sinne is die verbinding tussen die voorsetselwerkwoord en die naamwoordstuk baie hegter as die verbinding tussen die voorsetselwerkwoord en die voorsetselgroep.

voorsetselwerkwoord naamwoordstuk voorsetselgroep

Hy mak melding van die gebeure.

Ek doen 'n beroep op jou simpatie.

Hy hou 'n ogie oor die kinders. 
Wat die werkwoorde maak en doen betref, het Botha (1975) 'n verhelderende bydrae gelewer ten opsigte van die semantiese leegheid van hierdie werkwoorde. Hy gebruik die voorbeeldsinne
Die uitgewers doen stappe.
* Die uitgewers maak stappe.
Egipte maak oorlog.
* Egipte doen oorlog.

om daarop te wys dat doen [-kousatief] en maak [+kousatief] is.

Botha (1975) wys daarop dat die verskil tussen die twee werkwoorde daarin gelee is dat maak 'n "resulterende voorwerp" veronderstel, terwyl dit nie noodwendig met doen die geval is nie. Hy kom tot die slotsom dat doen dus semanties leër as maak is.

\subsection{NS + Wvs + NS + VG}

Voorsetselwerkwoorde kan ook refleksief optree (vgl. Ponelis, 1979:218) byvoorbeeld:

Ek begeef my op gevaarlike terrein.

Ons verlustig ons in die natuur.

Ek weerhou my liewer van kommentaar.

Ek verknies my oor die saak.

Ek vereenselwig my met die besluit.

\subsection{Vaste voorsetselgroepe kan deur voorsetselstroping tot 'n skoon naamwoordstuk ('n voorwerp) gewysig word}

\section{Voorbeelde:}

Die kinders spot met haar. - Die kinders spot haar.

Ek soek na die skêr. - Ek soek die skêr.

Ek skei van hom. - Ek skei hom.

Ek bejeën hom met agterdog. - Ek bejeën hom agterdogtig (Ponelis, 1979:200). 
In die sinne met 'n skoon naamwoordstuk is die hoofwerkwoord dus nie langer ' $n$ voorsetselwerkwoord nie, maar 'n gewone, oorganklike werkwoord.

\subsection{Deur voorsetselstroping kan voorsetselwerkwoorde tot oorgank- like werkwoorde met be-verander}

\section{Voorbeelde:}

Ek dink nog oor die saak. - Ek bedink nog die saak.

Ek kla oor my lot. - Ek bekla my lot.

Die span sorg altyd vir opwinding. - Die span besorg altyd opwinding (Ponelis, 1979: 201).

By die bogenoemde oorganklike werkwoorde word die voorwerp as geheel geraak, terwyl werkwoorde wat via 'n vaste voorsetsel met die voorsetselgroep verbind, net op 'n deel van die saak of klas sake waarna verwys word, betrekking het. Dieselfde geld by die volgende:

Hulle leer die liedjie. - Hulle leer aan die liedjie.

Hy lees die Bybel. - Hulle lees uit die Bybel.

Hy eet die wors. - Hy eet van die wors.

Hy betaal die kar af. - Hy betaal aan die kar af.

Ek ruik die rose. - Ek ruik aan die rose.

Die jakkalse vang die lammers. - Die jakkalse vang onder die lammers.

\subsection{Die voorsetsel van 'n voorsetselwerkwoord kan 'n werkwoord- deeltjie word}

\section{Voorbeelde:}

Lê die hande op hulle. (Lê hulle die hande op.)

Staan by my. (Staan my by.)

Raak aan hom. (Raak hom aan.) (Ponelis, 1979:201)

Uit die bogenoemde (afdeling 3.3, 3.4 en 3.5) moet geensins afgelei word dat die konstruksie met die voorsetsel die oorspronklike, ongemarkeerde, basiese of 
neutrale konstruksie is en dat die ander konstruksie van eersgenoemde afgelei is nie. Die een konstruksie bestaan naas die ander.

\subsection{Sekere deeltjiewerkwoorde vorm deel van die versameling voor-} setselwerkwoorde

Voorbeelde:

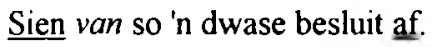

Die Naudes stam van ' $\mathrm{n}$ tradisievaste familie $\underline{\mathrm{af}}$.

Kom ons stap van die onderwerp af.

Hierdie voorbeelde wyk van die voriges af (Ponelis, 1979:232).

\subsection{Voorsetselwerkwoorde kan tegelykertyd refleksief optree en deel-} tjiewerkwoorde wees

Voorbeelde:

Ek $\underline{\text { lê my neer }} b y$ die bepalings.

Ek laat my uit oor die saak.

Jy dring jou op aan iemand.

Ons lê ons toe $o p$ besparing.

\subsection{Sommige refleksiewe voorsetselwerkwoorde kan net negatief ge-} bruik word

Voorbeeld:

Ek verdra hom nie voor my oë nie.

* Ek verdra hom voor my oë.

\subsection{Voorsetselwerkwoorde en idiomatiese uitdrukkings}

Dit was veral opvallend dat die hoofwerkwoord heel dikwels in idiomatiese uitdrukkings baie heg met die voorsetsel(groep) verbind:

Hy trou met die handskoen.

Hy speel om die keiser se baard. 
Benewens die naamwoordstuk wat as deel van die voorsetselgroep voorkom, kan baie van dié tipe voorsetselwerkwoorde boonop met nóg 'n naamwoordstuk verbind:

Werp jou brood op die water.

Hy maak nie 'n moordkuil van sy hart nie.

Hy slaan die hand aan die ploeg.

Sy optrede jaag 'n mens in die harnas.

\subsection{Die koppelwerkwoord + die voorsetseladjektief as voorsetsel- werkwoord}

Daar is reeds daarop gewys dat die voorsetseladjektief (Ponelis, 1979:276) in kombinasie met die koppelwerkwoord moet optree alvorens dit 'n ooreenkoms met 'n voorsetselwerkwoord kan vertoon. Vanweë hierdie verskynsel wil dit voorkom asof daar graduele verskille tussen die voorsetselwerkwoorde onderling voorkom. Bestudeer die volgende twee voorbeeldsinne:

(a) Ek hou van jou.

$$
W v s+V G
$$

(b) Ek is lief vir jou.

$$
\begin{aligned}
\text { Wkop }+ \text { VsAd } & +V G \\
W v s & +V G
\end{aligned}
$$

Dit is duidelik dat $\sin (a)$ en $\sin (b)$ nie dieselfde sintaktiese bou vertoon nie. In sin (a) kom 'n suiwer voorsetselwerkwoord voor, terwyl die koppelwerkwoord met die voorsetseladjektief moet verbind, alvorens dit 'n ooreenkoms met ' $n$ voorsetselwerkwoord kan vertoon, byvoorbeeld:

$\begin{array}{cll}\text { Koppelwerkwoord } & \text { voorsetseladjektief } & \text { voorsetselgroep } \\ \text { is } & \text { geheg } & \text { aan haar ouers } \\ \text { is } & \text { verslaaf } & \text { oan kos } \\ \text { is } & \text { begaan } & \text { oor die kinders } \\ \text { is } & \text { jaloers } & \text { op haar man }\end{array}$




$\begin{array}{lll}\text { is } & \text { ingenome } & \text { met die plan } \\ \text { is } & \text { behep } & \text { met sy motor } \\ \text { is } & \text { onderhewig } & \text { aan goedkeuring }\end{array}$

Dat sin (a) en (b) nie sintakties dieselfde bou vertoon nie, blyk uit die volgende voorbeeld:

(a) Hy ken sewe tale. - oorganklike werkwoord + direkte voorwerp

(b) Hy is sewe tale magtig. - koppelwerkwoord + naamwoordelike kopulapredikaat + adjektief

Sin (a) kan makliker in die passiefvorm omskryf word as (b):

(a) ? Sewe tale word deur hom geken.

(b) * Sewe tale word deur hom magtig gewees.

Dieselfde onderskeid geld ten opsigte van simne waarin die suiwer voorsetselwerkwoord optree en sinne met 'n koppelwerkwoord + 'n voorsetseladjektief wat optree asof die kombinasie ' $n$ voorsetselwerkwoord is:

(a) Ek hou van jou. - voorsetselwerkwoord

? Daar word van jou gehou.

(b) Ek is lief vir jou. - koppelwerkwoord + voorsetseladjektief

* Daar word vir jou lief gewees.

\section{Die verskillende tipes voorsetselwerkwoorde}

Dit het uit die literatuurstudie en die studievraelyste duidelik geword dat die voorsetselwerkwoord graduele verskille onderling openbaar.

\subsection{Die suiwer onoorganklike voorsetselwerkwoord}

Uit die studievraelyste was dit duidelik dat onoorganklikheid en oorganklikheid by die voorsetselwerkwoord 'n redelike mate van verwarring geskep het. Die onoorganklike voorsetselwerkwoord tree in noue verbintenis met die vaste voorsetsel(groep) op, maar nie in kombinasie met 'n naamwoordstuk nie:

Hierdie stelsel beantwoord aan sy doel.

Ek sal met die skuldiges afreken. 
Hierdie optrede stuur op 'n ramp af.

My besluit sal afhang van omstandighede.

Hulle heul met die vvand.

Hy bly hamer $O D$ die saak.

Ek sal $O D$ die saak ingaan.

\subsection{Die suiwer oorganklike voorsetselwerkwoord}

Die oorganklike voorsetselwerkwoord tree in kombinasie met 'n naamwoordstuk op. Hierdie naamwoordstuk tree as voorwerp by die voorsetselwerkwoord op.

Sy woorde stem my tot nadenke.

Sy herinner hom aan die vergadering (Botha \& Van Aardt, 1987:72).

Hulle het ons met klippe bestook.

Die voorsetselwerkwoord wat so in kombinasie met 'n naamwoordstuk optree, het dus oorganklike werkwoordeienskappe. Die sin Die Akademie bekroon hom met die Hertzogprys wat in die vraelyste voorgekom het, het verreweg die meeste probleme opgelewer. Veral ten opsigte van die oorganklikheid of onoorganklikheid van die voorsetselwerkwoord, was daar uiteenlopende opinies. Slegs $5 \%$ van die respondente het die voorsetselwerkwoord in hierdie sin as oorganklik beskou - $26 \%$ was van mening dat die voorsetselwerkwoord onoorganklik is!

\section{Die verband tussen die voorsetselwerkwoord en die partikel- werkwoord (deeltjiewerkwoord)}

Ponelis (1979:232) definieer 'n deeltjiewerkwoord as " $n$ baie hegte verbinding van 'n werkwoordelike element met ' $n$ ander element - die deeltjie - (wat van uiteenlopende aard kan wees), sodat die werkwoordelike element en die deeltjie saam 'n leksikale eenheid, 'n hoofwerkwoord, vorm". Vergelyk byvoorbeeld:

$\begin{array}{cll}\text { Werkwoordelike element } & \text { Deeltjie } & =\text { Hoofwerkwoord } \\ \text { kom } & \text { agter } & =\text { agterkom } \\ \text { pak } & \text { in } & =\text { inpak }\end{array}$

Die werkwoordelike element en die deeltjie kan nie los van mekaar benader word nie, maar vorm 'n eenheid: 
Haastig pak ek my klere in.

Haastig moes ek my klere inpak.

Hierdie hegte verbinding geld egter nie ten opsigte van die werkwoord en die voorsetsel nie:

Jan staan in die tuin.

* Jan moet die tuin instaan.

Deeltjiewerkwoorde kan onder bykans al die tipes hoofwerkwoorde voorkom, byvoorbeeld:

Ons beveel hierdie verandering aan (oorganklik).

Dit koel af (onoorganhlik).

Ek vra my dit $a f$ (wederkerend).

Dit hang van die ooreenkoms af (voorsetselwerkwoord).

Dit kom my voor of hulle onrustig is (koppelwerkwoord).

Volgens Ponelis (1979:233) onderskei Du Plessis (1972) 'n hele aantal ondertipe deeltjies, wat in wese meer met mekaar ooreenkom as verskil. Die noue verband wat daar soms tussen deeltjies en setsels kan voorkom, blyk duidelik uit die volgende voorbeelde:
Deeltjie
Setsel
bied my 'n sitplek aan
bied 'n sitplek aan my
blaai die boek deur
blaai deur die boek
spreek die volk toe
spreek $t o t$ die volk

Soms is daar egter geen aantoonbare verband tussen deeltjies en setsels nie: 


\section{Deeltjie}

durf hom aan

sinuk jou $o p$

leef jou uit
Setsel

* durf aan hom

* smuk op jou

* leef uit jou

Benewens die naamwoordelike, bywoordelike en adjektiwiese funksies van die deeltjies, tree voorsetselgroepe dikwels as deeltjies op (Ponelis, 1979:234):

$\begin{array}{ll}\text { Voorsetselgroep-as-deeltjie } & \text { Werkwoordelike element } \\ \text { aan die hand } & \text { doen } \\ \text { aan die pen } & \text { ry } \\ \text { in die hande } & \text { kry }\end{array}$

Die werkwoordelike element + die voorsetselgroep-as-deeltjie toon 'n ooreenkoms met die voorsetselwerkwoord + die vaste voorsetselgroep, omdat die werkwoordelike element sowel as die voorsetselwerkwoord 'n vaste voorsetsel determineer:

$$
\begin{array}{lll}
\text { doen aan die hand } & / & \text { kla oor die kos } \\
\text { ry aan die pen } & / & \text { berus in sy lot }
\end{array}
$$

Die werkwoordelike element determineer egter ' $n$ vaste voorsetselgroep, terwyl die voorsetselwerkwoord slegs 'n vaste voorsetsel determineer:

doen aan die hand - kla oor die kos / die behandeling

Ry aan die pen - berus in sy lot / die onvermydelike

Deeltjiewerkwoorde is leksikale eenhede wat deur onskeibare leksikale eenhede vervang kan word (Ponelis, 1979:235):

aan die hand doen: voorstel

aan die pen ry: boet

in die hande kry: verkry 
Die deeltjies en die werkwoordelike element kan 'n nominaalkonstruksie vorm (Ponelis, 1979: 236):

$\begin{array}{ccl}\text { Deeltjie } & + \text { werkwoordelike element } & \text { Nominaal } \\ \text { aan } & \text { beveel } & \text { aanbeveling } \\ \text { aan } & \text { dring } & \text { aandrang }\end{array}$

Hoewel daar ' $n$ hegte verbondenheid tussen die werkwoordelike element en werkwoorddeeltjie is, tree hulle as afsonderlike woorde in die spilposisie en die sentrumgrens op:

Baie mense wyk van die tradisie $a f$.

Sodra die werkwoordelike gedeelte ook in die sentrumgrens optree, vind 'n byeenplasing plaas:

Baie mense sal van die tradisie afwyk.

\section{Opsomming}

In hierdie artikel is die wese en die optrede van die voorsetselwerkwoord van nader beskou. Die wesenskenmerke van die voorsetselwerkwoord is soos volg gestel:

- Die voorsetselwerkwoord determineer ' $n$ vaste voorsetsel.

- Die voorsetselwerkwoord vereis 'n voorsetselvoorwerp waarmee dit heg verbind.

- Die voorsetselgroep wat saam met die voorsetselwerkwoord optree, kan nie sonder meer deur één woord vervang word nie.

Die optrede van die voorsetselwerkwoord is soos volg uitgelig:

- Die voorsetselwerkwoord determineer soms benewens die voorsetselgroep 'n naamwoordstuk wat as voorwerp van die werkwoord optree, en het dus oorganklike werkwoordkenmerke. Soms is die verbinding tussen die voorsetselwerkwoord en die voorsetselgroep baie hegter as die verbinding tussen die voorsetselwerkwoord en die naamwoordstuk wat as voorwerp van die werkwoord optree, byvoorbeeld:

Sy herinner hom aan die vergadering. 
In sommige gevalle is die verbinding tussen die voorsetselwerkwoord en die naamwoordstuk wat as voorwerp van die werkwoord optree, weer hegter:

Hy maak melding van die gebeure.

Sy skenk aandag aan hom.

- Voorsetselwerkwoorde kan ook refleksief optree.

- Deur voorsetselstroping kan vaste voorsetselgroepe tot skoon naamwoordstukke gewysig word, sodat die betrokke hoofwerkwoord ook dan nie langer 'n voorsetselwerkwoord is nie, maar 'n oorganklike werkwoord.

- Deur voorsetselstroping kan voorsetselwerkwoorde tot oorganklike werkwoorde met be-verander.

- Die voorsetsel van 'n voorsetselwerkwoord kan 'n werkwoorddeeltjie word.

- Sekere deeltjiewerkwoorde vorm deel van die versameling voorsetselwerkwoorde.

- Voorsetselwerkwoorde kan tegelykertyd refleksief optree en deeltjiewerkwoorde wees.

- Sommige refleksiewe voorsetselwerkwoorde kan net negatief gebruik word.

- In idiomatiese uitdrukkings verbind die voorsetselwerkwoord dikwels baie heg met die voorsetselgroep, omdat dit 'n vaste uitdrukking vorm.

- Die voorsetseladjektief moet in kombinasie met die koppelwerkwoord optree, alvorens dit soos 'n voorsetselwerkwoord optree.

Daar is gewys op die verskil tussen die suiwer onoorganklike voorsetselwerkwoord en die suiwer oorganklike voorsetselwerkwoord.

In die lig van bogenoemde bespreking is dit duidelik dat die voorsetselwerkwoord inderdaad 'n gekompliseerde tipe hoofwerkwoord met unieke wesenseienskappe is, wat hierdie kategorie hoofwerkwoord tot 'n regmatige hoofwerkwoord verhef.

\section{Bibliografie}

Botha, J.P. \& Van Aardt, J.M H 1978 Afrikaans vir die praktyk. Johannesburg : Lexiconuitgewers

Botha, J.P. 1985. Afrikaanse sintaksis vir voorgraadse studente. Johannesburg : McGraw-Hill Boekmaatskappy

Botha, J.P \& Van Aardt, J.M.H 1987. Afrikaans vir die praktyk. Johannesburg : Lexiconuitgewers 
Botha, W.J. 1975. Die lee werkwoord in Afrikaans Pretoria : UNISA. (M.A.-verhandeling.) De Beer, J.A. \& Van Staden, M J 1986. Funksionele taalkunde. Bailliepark : Inter-kampus Publikasies (Edms.) Bpk.

De Villiers, Meyer 1983. Afrikaanse grammatika vir volwassenes. Goodwood: Nasou Beperk

Du Plessis, Hans. 1982. Simtaksis vir eerstejaars. Pretoria : Academica

Du Plessis, H.G.W 1972. Die deeltjiewerkwoord in Afrikaans. Pretoria : UNISA (M.A.verhandeling.)

Ponelis, F.A 1968. Grondtrekke van die Afrikaanse sintaksis. Pretoria : Van Schaik Bpk.

Ponelis, F A. 1979 Afrikaanse sintaksis. Pretoria : Van Schaik.

Van Schoor, J.L. 1983 Grammatika van standaard-Afrikaans. Kaapstad : Lex Patria Uitgewers

\section{Universiteit Vista (Kampus vir Verdere Opleiding) Pretoria}

